\title{
Temporal and spatial stability of bacterioplankton biomass and productivity in an atoll lagoon
}

\author{
Jean-Pascal Torréton*, Philippe Dufour \\ Centre ORSTOM de Tahiti, BP 529, Papeete, French Polynesia
}

\begin{abstract}
Spatial and temporal variations of bacterioplankton biomass, production and growth rates were investigated 6 times from 1991 to 1994 in Tikehau lagoon (Tuamotu, French Polynesia). The water column was homogeneous from the surface to the bottom $(20 \mathrm{~m})$ at the reference station but some horizontal variations were detected, with biomass and production increasing from the reef-flat spillways (oceanic water inflow) to the main part of the lagoon and decreasing from the relatively eutrophic shore (near the village) to the main part of the lagoon. However, both of these perturbations were limited to the immediate vicinity of these areas. Diel fluctuations of bacterial biomass and growth rate were slight (coefficient of variation, CV $<20 \%$ ) and showed no significant pattern. Day-to-day variations recorded over periods of up to 20 consecutive days appeared also to be limited ( $\mathrm{CV}<25 \%$ ). A significant correlation between wind and total abundance of bacteria in the water column suggested that these day-today variations may be in part explained by wind, probably inducing resuspension of sediments. No significant pattern appeared from comparison of the 6 cruises spread over different seasons. Cruise averages differed slightly from each other, with CV for all cruises averaging 34,10 and $41 \%$ for bacterioplankton biomass, production and growth rate, respectively. Tikehau lagoon appears to be a very stable ecosystem for bacterioplankton processes and therefore differs strongly from other reef water column systems. This untypical stability might be explained by the long residence time of water ( $170 \mathrm{~d})$, the strong stability of the oceanic surrounding water (South Pacific Gyre), the weak seasonality of primary producers and the limited inputs from corals, bordering islands and sediments.
\end{abstract}

KEY WORDS: Bacterioplankton B Bacterial production - Thymidine incorporation - Leucine incorporation Atoll lagoon Pacific Ocean

\section{INTRODUCTION}

The development of epifluorescence microscopy and tracer approaches has led to a better understanding of the contribution of heterotrophic bacterioplankton to the cycles of energy and matter in various pelagic ecosystems. Heterotrophic bacteria are recognized to play a key role in most of the aquatic systems studied and particularly in oligotrophic waters where efficient recycling processes are crucial. This is consistent with the increase in the bacterioplankton to phytoplankton biomass ratio from eutrophic to oligotrophic systems (Cho \& Azam 1990, Dufour \& Torréton 1996).

Coral reefs areas are characterized by fast and efficient nutrient recycling processes and low standing

\footnotetext{
•E-mail: torreton@tahiti.rio.net
}

stocks and inputs of new nutrients (Crossland \& Barnes 1983). Understanding the production and fate of detritus is thus of great importance for the comprehension of the processes governing these ecosystems. The determination of bacterial production of biomass and heterotrophic activity represents an attractive shortcut to integrate the detrital fluxes coming from the wide variety of potential sources in coral reefs environments (Ducklow 1990).

Using the average surface area of 99 atolls (Stoddart 1965), Kinsey \& Hopley (1991) calculated that the 425 atolls on the earth would represent $115000 \mathrm{~km}^{2}$ and thus $19 \%$ of the total area $\left(617000 \mathrm{~km}^{2}\right)$ covered by coral reef ecosystems (Smith 1978). Atoll and island lagoons often represent large bodies of oligotrophic water where heterotrophic bacterioplankton may constitute a large proportion of total carbon, nitrogen and phosphorus. Knowledge of bacterioplankton dynamics 
is thus essential in understanding the flows of energy and matter in these lagoons. However, most of the studies on bacterioplankton in coral reef environments have focused on the water overlying coral reefs (Sorokin 1973, 1978, Moriarty et al. 1985, 1990, Linley \& Koop 1986, Hoppe et al. 1988, Ducklow 1990, Ayukai 1995) with only a few exceptions in atoll lagoons (in Majuro: Sorokin 1978, Yoshinaga et al. 1991; in Tuamotu: Torréton \& Dufour 1996), and Island lagoons (Sorokin 1973, Landry et al. 1984, Yoshinaga et al. 1991).

Reliable carbon and nutrient budgets are almost impossible to establish without estimating the representativeness of the measurements made during single cruises. The temporal variability of bacterioplankton biomass and activity is high in water ovcrlying coral reefs due to tide currents (Linley \& Koop 1986, Hoppe et al, 1988), diurnal rhythms (Moriarty et al. 1985), resuspension with increasing wind speed (Moriariy 1979) and seasonal changes (Moriarty et al. 1985) and/or interannual variations.

For example, on a diel basis, Linley \& Koop (1986) reported production variations up to 14 -fold in lagoon waters and up to 25 -fold in reef-flat waters of One Tree Island with a maximum generally during low tide. At Lizard Island, Moriarty et al. (1985) showed production values varying from 2 -fold in the lagoon up to 7 -fold at the reef front with a maximum in the afternoon.

Production values determined in winter and summer 1982 at Lizard Island differ by about 22-fold in the lagoon and 78 -fold at the reef-flat (Moriarty et al. 1985). These temporal variations are considerable and suggest a close coupling between substrate supply and bacterial growth. However, they also prevent the establishment of carbon and nutrient budgets with reasonable accuracy using data obtained from temporally limited studies. In coral reef systems, spatial variations appear also quite important; a 7 -fold variation in growth rates was reported by Moriarty et al. (1985) at Lizard Island during ebb tide while Linley \& Koop (1986) reported a 15 -fold variation along a $2.5 \mathrm{~km}$ transect over Davies Reef.

In contrast to repeated studies on the Great Barrier Reef, and probably due to their poor accessibility, studies on bacterioplankton processes in oceanic atolls have only been performed during oceanographic cruises (Sorokin 1973, 1978, Yoshinaga et al. 1991), preventing evaluation of the temporal and spatial variability of bacterial biomass and activity. The seasonal variations in oceanic atolls isolated from continental masses and situated in low latitudes may be expected to be smaller than those reported in the Great Barrier Reef. Indeed, in Tikehau lagoon chlorophyll a (chl a) and particulate organic carbon (POC) vary only by about 1.3-and 1.6-fold respectively with maxima dur- ing austral winter $\left(0.24 \mu \mathrm{g}^{-1}\right.$ and $\left.240 \mu \mathrm{g} \mathrm{C} \mathrm{l}^{-1}\right)$ and minima during austral summer $\left(0.18 \mu \mathrm{g}^{-1}\right.$ and $150 \mu \mathrm{g}$ $\mathrm{C}^{-1}$; Charpy \& Charpy-Roubaud 1991). In contrast, irradiance is minimal ( $36 \mathrm{E} \mathrm{m}^{-2} \mathrm{~d}^{-1}$ ) during austral winter and maximal (56 $\mathrm{E} \mathrm{m}^{-2} \mathrm{~d}^{-1}$ ) during summer, and total (pelagic+benthic) primary production estimated from light and chl a have been estimated to vary between 0.53 and $0.65 \mathrm{~g} \mathrm{C} \mathrm{m}^{-2} \mathrm{~d}^{-1}$ in winter and summer, respectively (Charpy \& Charpy-Roubaud 1990). Fluctuations of bacterial biomass and productivity should therefore be moderate at these scales. However, a possible close coupling between primary production and bacterial production could lead to significant variations of at least bacterial production at the daily scale. Resources for microbial growth could also be lower between areas near the reef-flat spillways where oceanic water enters than in the central part of the Iagoon. On the other hand, microbial growth should be greater near sites where human activity may lead to significant enrichment relative to inside a lagoon. Here, we present the results of a study of spatial and temporal variations of bacterioplankton biomass and productivity in the water column of Tikehau atoll lagoon. The questions we addressed were the following: What is the range of temporal variability in bacterial production and growth rates in the water column of this atoll lagoon? Are discrete measurements of these bacterioplanktonic variables representative of the 'average' conditions prevailing in this ecosystem? What is the extent of the presumable spatial gradients of bacterioplankton processes in the ecosystem? Do they prevent the extrapolation of measurements made at a limited number of stations inside the lagoon? For this purpose, different spatial scales were investigated including vertical profiles and horizontal variation from the shore to the main part of the lagoon and from a reef-flat spillway to the main part of the lagoon. Variation of bacterial abundance and activity was assessed over time scales ranging from hours to seasons. We are aware that studies of bacterioplanktonic process variability at smaller scales, such as the minute scale for temporal variations and the centimeter scale for spatial variations, may be useful to understand the physical and biological factors regulating bacterial populations (see for example Ducklow 1984, Paul et al. 1986, Schiller \& Herndl 1989). This is, however, beyond the scope of this study.

\section{MATERIALS AND METHODS}

Study site. Tikehau atoll $\left(14^{\circ} 55^{\prime} \mathrm{S}, 148^{\circ} 15^{\prime} \mathrm{W}\right.$ ) is situated in the northwest of the Tuamotu Archipelago (French Polynesia). The lagoon has an area of $400 \mathrm{~km}^{2}$ with an average depth of $25 \mathrm{~m}$ (Lenhardt 1991). 
Oceanic waters enter the lagoon mostly through reefflat spillways situated on the southern and eastern parts of the atoll while the main exit is via a permanent passage $(200 \mathrm{~m}$ wide, $3.7 \mathrm{~m}$ deep) on the west side (Fig. 1). Water residence time ranges from 100 to $230 \mathrm{~d}$ in austral winter and summer, respectively, and averages annually $170 \mathrm{~d}$ (Lenhardt 1991). Nutrient budgets (Charpy-Roubaud et al. 1990), phytoplankton and phytobenthos productivity (Charpy \& Charpy-Roubaud 1990), zooplankton (Leborgne et al. 1989) and particulate organic matter standing stocks and fluxes (Blanchot et al. 1989, Charpy \& Charpy-Roubaud 1991) have been described previously.

Sampling. The present work was performed during 6 field trips in Tikehau in January 19 to 25, 1991, November 9 to 15,1991 (start of the rainy season), March 15 to 21, 1992 (end of the rainy season), November 8 to 22, 1992, May 16 to June 3, 1993 and July 31 to August 19, 1994 (dry season). During the 6 field trips, samples were collected daily (at 09:00 or at 16:00 h) from the lagoon reference station at $0.5 \mathrm{~m}$ depth (total depth of station $20 \mathrm{~m}$; Fig. 1) representative of the main part of Tikehau lagoon (average depth $25 \mathrm{~m}$ ). Two diel studies were conducted on November 17 to 18,1992 , and May 24 to 25, 1993. Bacterial variables were determined for 10 vertical profiles during the November 1991, March 1992, November 1992 and May 1993 studies. Water characteristics in a reef-flat spillway were studied at the reference spillway station bordering the village island to the east. This opening is $800 \mathrm{~m}$ long and $150 \mathrm{~m}$ wide with an average depth less than $1 \mathrm{~m}$. The hydrodynamic characteristics of this spillway were studied previously (Lenhardt 1991). Oceanic surface $(0.5 \mathrm{~m}$ deep) water samples were collected on the southern part of the atoll (Fig. 1). Water samples were collected using acidwashed Niskin bottles and treated at the ORSTOM field station within $1 \mathrm{~h}$ after sampling. All sample handling was performed using either disposable sterile hardware or acid-washed polycarbonate bottles.

Bacterial parameters. Bacterial abundance was determined using epifluorescence microscopy (Porter \& Feig 1980). The percentage of bacteria attached to particles and the frequency of dividing-divided cells (FDDC; Newell \& Christian 1981) were distinguished on the same filters. Bacterial activity was estimated using [methy]- ${ }^{3} \mathrm{H}$ ] thymidine (TdR) incorporation into DNA (Fuhrman \& Azam 1982) and $\left[4,5-{ }^{3} \mathrm{H}\right]$ leucine (Leu) incorporation into proteins (Kirchman et al. 1985). The protocols employed in this study are described in detail elsewhere (Torréton \& Dufour 1996). Conversion factors for TdR and Leu were determined in unenriched batch cultures of lagoon water using a cumulative calculation method (Bjørnsen \& Kuparinen 1991). Conversion factors for TdR and Leu

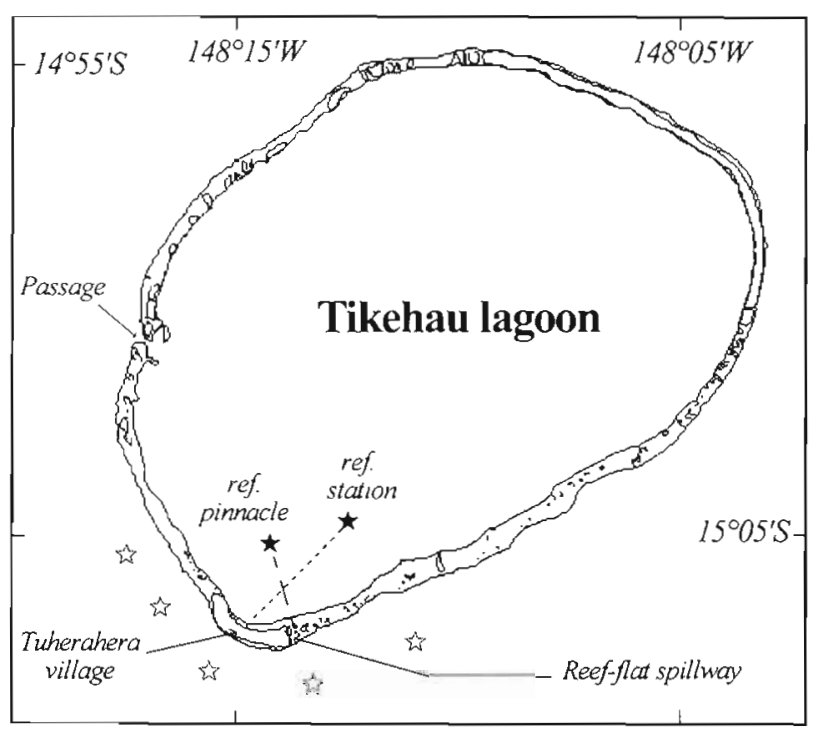

Fig. 1. Map of Tikehau atoll showing the reference station. Pinnacles are abundant in the lagoon, but the reference pinnacle is the only one represented. Dotted and dashed lines represent village to reference station and reference reef-flat spillway to lagoon transects, respectively. Oceanic stations (⿻) were visited twice on May 22 and 24, 1993

averaged $\left( \pm\right.$ SD) $0.80( \pm 0.29) \times 10^{18}$ and $0.91( \pm 0.34) \times$ $10^{17}$ cells $\mathrm{mol}^{-1}$, respectively (Torréton \& Dufour 1996). The average Leu/TdR ratio is 13.1 in Tikehau lagoon, and TdR and Leu derived production values do not differ significantly (Torréton \& Dufour 1996). Therefore, the weight average of $0.99 \times 10^{18}\left[\left(0.80 \times 10^{18}+0.91 \times\right.\right.$ $\left.\left.10^{17} \times 13.1\right) / 2\right]$ and $0.76 \times 10^{17}$ cells $\mathrm{mol}^{-1}[(0.80 \times$ $\left.\left.10^{18} / 13.1+0.91 \times 10^{17}\right) / 2\right]$ were calculated for $\mathrm{TdR}$ and Leu conversion factors, respectively. Replicate determinations differed on average by less than $10 \%$ for total bacterial counts, $15 \%$ for FDDC and $6 \%$ for TdR and Leu incorporation rates. The percentage of attached cells is less precise as $4 \%$ attached bacteria (average in the lagoon) represent only 16 cells out of 400 (minimum of cells enumerated per sample) and depends greatly on the presence of rare particles in the fields examined. We thus consider that only average values per cruise are significant using this procedure.

Statistical analysis. Correlation and regression analyses were performed according to Snedecor \& Cochran (1957).

\section{RESULTS}

\section{Spatial variations}

Vertical variations. To examine the vertical distribution of bacterioplankton parameters in the water column, a total of 10 profiles of bacterioplankton parame- 
ters were taken at the reference station $(20 \mathrm{~m})$. Bacterial parameters showed little variation through the water column with average coefficients of variation (CV) of 10,14 and $18 \%$ for bacterial abundance, production and growth rate, respectively. When all the values were expressed as a percentage of the water column average no significant trend was noticeable (Fig. 2). The water column may thus be considered homogenous for bacterioplankton parameters in this lagoon.

Horizontal variations. Horizontal homogeneity of POC (particulate organic carbon), PON (particulate organic nitrogen), POP (particulate organic phosphorus), ATP (adenosine triphosphate) and pigments has been reported at the lagoon scale by Charpy \& Charpy-Roubaud, (1991) and for nutrients by CharpyRoubaud et al. (1990). This justified the use of 1 lagoon reference station (see Fig. 1). We investigated horizontal variations in bacteriopianktonic abundance and activity at a smaller scale along 2 different transects: from the village to the reference station and from a reef-flat spillway to the main lagoon (Fig. 1).

Village to the reference station transect: Bacterial numbers showed little differences along the transect (Fig. 3). TdR incorporation rate decreased sharply from

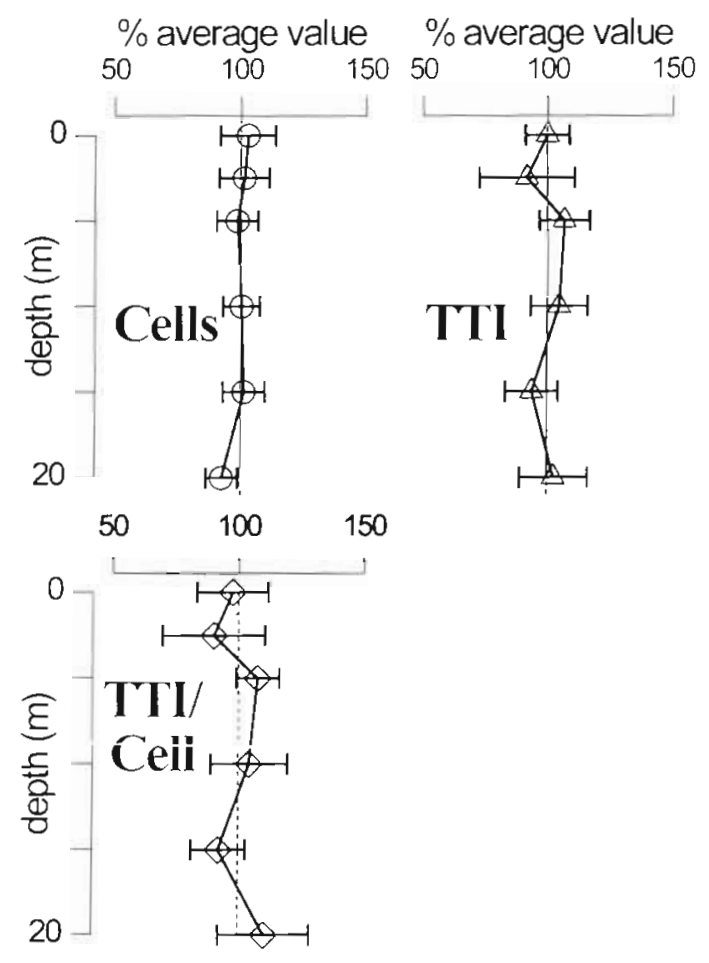

Fig. 2. Average vertical profiles for abundance (Cells), production ( ${ }^{3} \mathrm{H}$ thymidine incorporation. TTI) and growth rates (TTl/cell) of bacterioplankton expressed as a percentage of the average values for each water column. Error bars represent standard deviations $(n=10)$
69-82 pmol $\mathrm{l}^{-1} \mathrm{~h}^{-1}$ near the shore to $12-14 \mathrm{pmol} \mathrm{l}^{-1} \mathrm{~h}^{-1}$ between 150 and $4500 \mathrm{~m}$ from the beach. High values near the beach were reflected in calculated bacterial generation times or $0.7-0.9 \mathrm{~d}$ in the first $100 \mathrm{~m}$ from the beach compared to 3.4-4.7 d further into the lagoon. Leu incorporation rates followed the same pattern as TdR. Maximum values (900 to $1200 \mathrm{pmol} \mathrm{l}^{-1} \mathrm{~h}^{-1}$ ) were recorded at the 2 stations near the beach and Leu incorporation decreased drastically to $100-120 \mathrm{pmol}^{-1}$ $\mathrm{h}^{-1}$ into the main part of the lagoon. The differences were also reflected in FDDC values which ranged from $10.4-12.7 \%$ near the village to $6.7-8.3 \%$ in the main part of the lagoon. The nearshore increase of bacterioplankton variables, probably related to human activities, seems thus limited to the first $100 \mathrm{~m}$ from the shore (Fig. 3)

Reef-flat spillway characteristics: On May 23, 1993, bacterial parameters and water velocity were recorded cvery $2 \mathrm{~h}$ over a tidal rycle in the reef-flat spillway (Fig. 4). Current speed ranged from 6 to $29 \mathrm{~cm} \mathrm{~s}{ }^{1}$ averaging $14 \mathrm{~cm} \mathrm{~s}^{-1}$ This value is close to the annual influx average $\left(11 \mathrm{~cm} \mathrm{~s}^{-1}\right.$; Lenhardt 1991) through this reefflat spillway. Bacterial abundance and activity appeared to be maximal at the beginning of the inflow and decreased through the tidal cycle. Water flowing through the reef-flat spillway showed bacteriological characteristics distinct from average bacterial parameters in oceanic waters at the same times (May 22 and 24; see location in Fig 1) indicating some changes during the flow. Four significant differences were observed (Table 1):

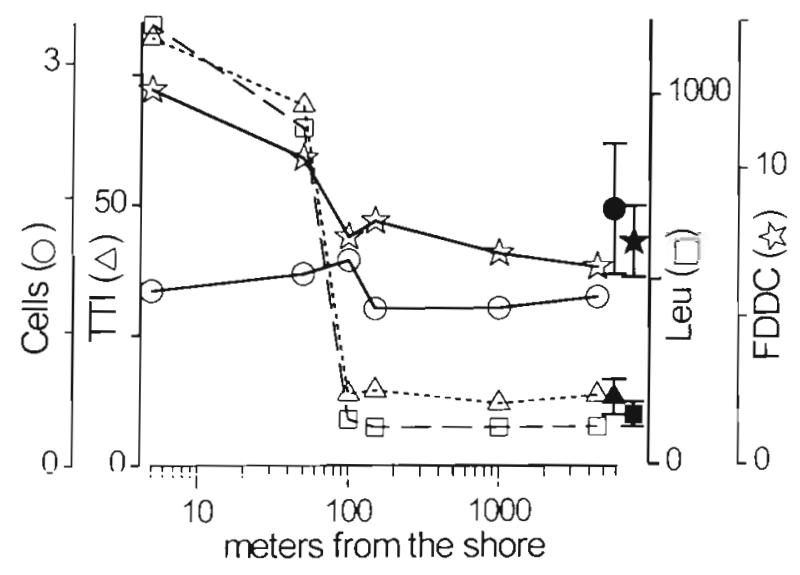

Fig. 3. Change in abundance (Cells, $10^{4} \mathrm{I}^{-1}$ ), ${ }^{3} \mathrm{H}$-thymıdine incorporation (TTI, pmol $\left.\mathrm{l}^{-1} \mathrm{~h}^{-1}\right),{ }^{3} \mathrm{H}$-leucine incorporation (Leu, pmol $\mathrm{l}^{-1} \mathrm{~h}^{-1}$ ) and frequency of dividing-divided cells (FDDC, \%) along a transect from the shore to the lagoon reference station (November 13, 1992). Filled symbols and error bars on the right represent average values and standard deviations in Tikehau lagoon reference station during the same study period $(n=14)$ 


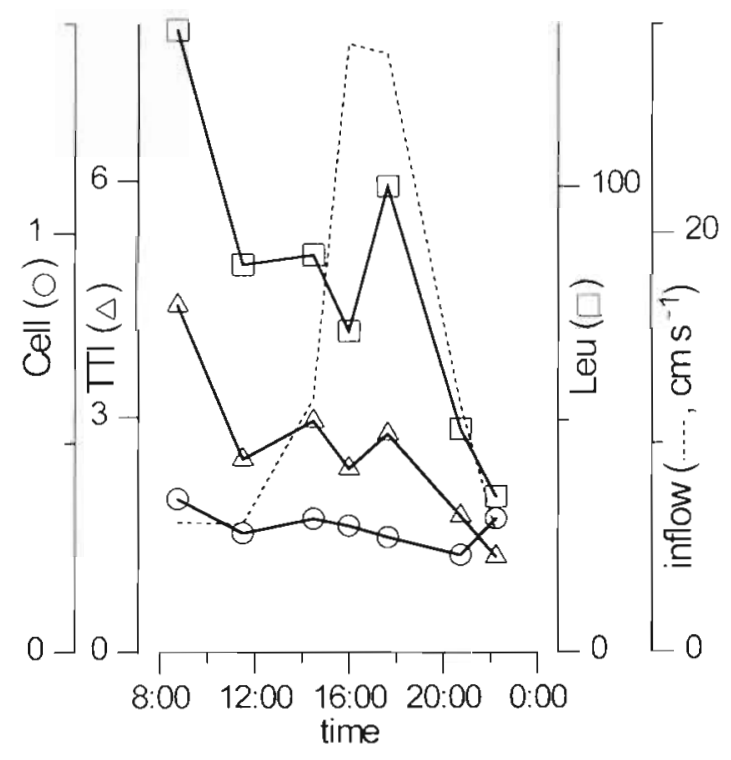

Fig. 4. Temporal variations in bacterial variables recorded in water flowing across a reef-flat spillway. Dotted line represents inflow speed. Symbols and units as in Fig. 3

- a $33 \%$ decrease of cell numbers (average $0.3 \times$ $10^{9}$ cells $\mathrm{l}^{-1}$ ) relative to the ocean (average $0.45 \times$ $10^{9}$ cells $1^{-1}$ ).

- an increase of specific $T d R$ incorporation rate per cell by 3.2 -fold on average. This increase in bacterial activity reflects better growth conditions in the reefflat spillway than in oceanic waters. If we assume that the average $\mathrm{TdR}$ conversion factor determined in the lagoon $\left(0.99 \times 10^{18}\right.$ cells $\left.\mathrm{mol}^{-1}\right)$ may be applied to reefflat spillway and oceanic waters, with 8.4 and $2.6 \times$ $10^{-21} \mathrm{~mol} \mathrm{cell}^{-1} \mathrm{~h}^{-1}$ (Table 1 ) bacteria showed average generation times $(1 / \mu)$ of 5 and $16 \mathrm{~d}$, respectively.

- an increase of specific Leu incorporation rate per cell by 4.1 -fold on average, thus a greater increase than for $T d R$ incorporation. This led to a significant ( $p<$ 0.01 ) increase of the Leu/TdR ratio from 24 in oceanic waters to 31 in the reef-flat spillway.

- an increase of the number and proportion of attached cells (7.4\%) compared to oceanic waters $(1.5 \%)$.

Reef-flat spillway to lagoon transect: A transect between the reef-flat spillway and the main part of the lagoon was investigated on November 12, 1992. Inflow speed was $11 \mathrm{~cm} \mathrm{~s}^{-1}$, a value very close to the annual average (see above). Low abundances, typical of reefflat spillway values $\left(0.3\right.$ to $0.4 \times 10^{9}$ cells $\left.\mathrm{I}^{-1}\right)$, were found up to $200 \mathrm{~m}$ inside the lagoon and increased sharply to $1.3 \times 10^{9}$ cells $\mathrm{l}^{-1} 300 \mathrm{~m}$ inside and further (Fig. 5). The same pattern was observed for TdR incorporation rates with values between 1.0 and $1.3 \mathrm{pmol} \mathrm{l}^{-1}$ $\mathrm{h}^{-1}$ from the spillway to $200 \mathrm{~m}$ into the lagoon, increasing to $17-21 \mathrm{pmol} \mathrm{l}^{-1} \mathrm{~h}^{-1} 300 \mathrm{~m}$ or further inside the lagoon. FDDC increased in parallel from $3.6 \%$ in the spillway to $7 \%$ in the lagoon.

The influence of the reef-flat spillway seems thus limited to less than $300 \mathrm{~m}$ into the lagoon during an $11 \mathrm{~cm} \mathrm{~s}^{-1}$ inflow. At $300 \mathrm{~m}$ from the reef-flat spillway opening to the lagoon, bacterial parameters were quite typical of lagoonal values (Fig. 5).

\section{Temporal variations}

Diel variations. The diel cycles of abundance and activity were studied on November 17, 1992, and on May 24, 1993, using samples collected at $0.5 \mathrm{~m}$ at the reference station. Results (Table 2) show that diurnal variations were very slight with coefficients of variation always less than $20 \%$ for bacterial abundance, production (TdR and Leu) and growth rate indexes (FDDC, TdR/cell and Leu/cell), with no significant trend with time of day.

Table 1. Lagoon, reef-flat spillway and oceanic water characteristics in May 1993. Cells: total bacterial abundance $\left(10^{9} \mathrm{I}^{-1}\right)$; FDDC: frequency of dividing-divided cells (\% of total): \%ATT: percentage of attached cells; TTI: tritiated thymidine incorporation (pmol $\left.\mathrm{l}^{-1} \mathrm{~h}^{-1}\right)$; Leu: leucine incorporation $\left(\mathrm{pmol} \mathrm{l}^{-1} \mathrm{~h}^{-1}\right)$; TTl/cell: thymidine incorporation rate per cell $\left(10^{-21} \mathrm{~mol} \mathrm{l}^{-1} \mathrm{~h}^{-1}\right)$; Leu/cell: leucine incorporation rate per cell $\left(10^{-21} \mathrm{~mol} \mathrm{l}^{-1} \mathrm{~h}^{-1}\right)$. p: significance of the differences between reef-flat spillway and oceanic water averages was determined using a non-parametric Mann-Whitney test. ns: not significant; $p<0.05 ;{ }^{\prime} p<0.01 ; \cdots p<0.001$

\begin{tabular}{|c|c|c|c|c|c|c|c|c|c|}
\hline Site & & Cells & FDDC & $\%$ ATT & ТГI & Leu & TTI/cell & Leu/cell & Leu/TTI \\
\hline Lagoon & Mean & 2.37 & 8.1 & 2.1 & 11.9 & 168 & 5.1 & 71 & 14 \\
\hline May 16 to June $3(n=19)$ & $\mathrm{SD}$ & 0.27 & 1.8 & 2.1 & 2.2 & 31 & 1.1 & 13 & 2 \\
\hline Reef-flat spillway & Mean & 0.30 & 7.9 & 7.4 & 2.6 & 79 & 8.4 & 260 & 31 \\
\hline $\operatorname{May} 23(n=7)$ & $\mathrm{SD}$ & 0.06 & 1.0 & 3.4 & 1.0 & 33 & 2.6 & 92 & 3 \\
\hline Ocean & Mean & 0.45 & 4.8 & 1.5 & 1.2 & 28 & 2.6 & 64 & 24 \\
\hline May 22 and $24(n=10)$ & $\mathrm{SD}$ & 0.08 & 0.9 & 1.7 & 0.2 & 6 & 0.7 & 18 & 3 \\
\hline p: reef-flat spillway/ocean & & $\cdots$ & .. & .. & $\cdots$ & .. & $\cdots$ & $\cdots$ & -. \\
\hline p: reef-flat spillway/lagoon & & $\cdots$ & ns & .. & $\cdots$ & $\cdots$ & $\cdots$ & $\cdots$ & $\cdots$ \\
\hline p: ocean/lagoon & & $\cdots$ & $\cdots$ & ns & $\cdots$ & $\cdots$ & $\cdots$ & $n s$ & $\cdots$ \\
\hline
\end{tabular}




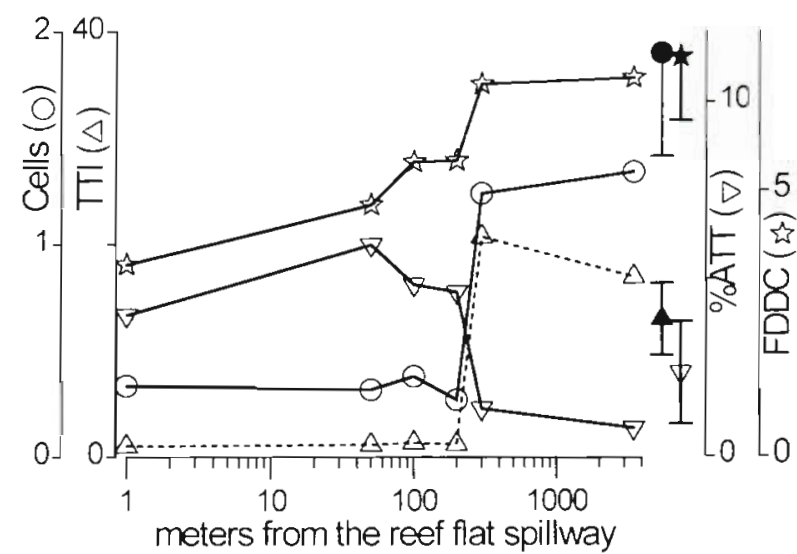

Fig. 5. Change in bacterioplankton variables along a transect from the reference reef-flat spillway to the lagoon reference station (November 12,1992). \%ATT: percentage of attached bacteria; other symbols and units as in Fig. 3. Filled symbols and error bars on the right represent average values and standard deviations in Tikehai lagoon during the same study period $(n=14)$

Day-to-day fluctuations. Bacterial parameters were recorded every day at 09:00 $\mathrm{h}$ based on samples at the reference station ( $0.5 \mathrm{~m}$ depth) over periods ranging from 1 to $3 \mathrm{wk}$ during the 6 cruises. Ali the parameters varied slightly from day to day with $\mathrm{CV}$ values around $20 \%$ for bacterioplankton biomass, production and growth rate (Table 3 ). The range of variation (maximum/minimum) for each study period was limited to 2.2-fold for bacterial abundance and TTI incorporation, 2.9-fold for Leu incorporation and 3.6-fold for specific incorporation rates per cell.

We tried to examine whether wind velocity influenced day-to-day variability of bacterial processes. Wind speed was recorded continuously during the last 2 field trips. In the May 1993 and August 1994 study periods, as usual in austral winter (Lenhardt 1991), dominant winds were from the southeast. When correlations were examined between bacterial parameters and wind speed averaged $24 \mathrm{~h}$ before sampling, wind speed appeared to have a significant influence on total abundance (Fig. 6). Wind speed averages $4.9 \mathrm{~m} \mathrm{~s}^{-1}$ yearly in

Table 2. Average (Avg.), coefficient of variation (CV\%) and maximum amplitude (Max/min ố bacteriopiankion pa ameters determincd cvory 3 h along 2 diurnal cycles ( 9 values for each cycle). Symbols and unıts as in Table 1

\begin{tabular}{|llcccccc|}
\hline Date & & Cell & FDDC & TTl & Leu & TTl/cell & Leu/cell \\
\hline Nov 17, 1992 Avg. & 2.18 & 8.4 & 16.9 & 182 & 7.8 & 84 \\
& CV\% & 7 & 14 & 13 & 10 & 16 & 9 \\
& Max/min & 1.3 & 1.6 & 1.4 & 1.3 & 1.5 & 1.4 \\
May 24. 1993 Avg. & 2.27 & 8.0 & 13.1 & 191 & 5.8 & 85 \\
& CV\% & 5 & 15 & 10 & 14 & 13 & 16 \\
& Max/min & 1.2 & 1.7 & 1.4 & 1.5 & 1.5 & 1.7 \\
\hline
\end{tabular}

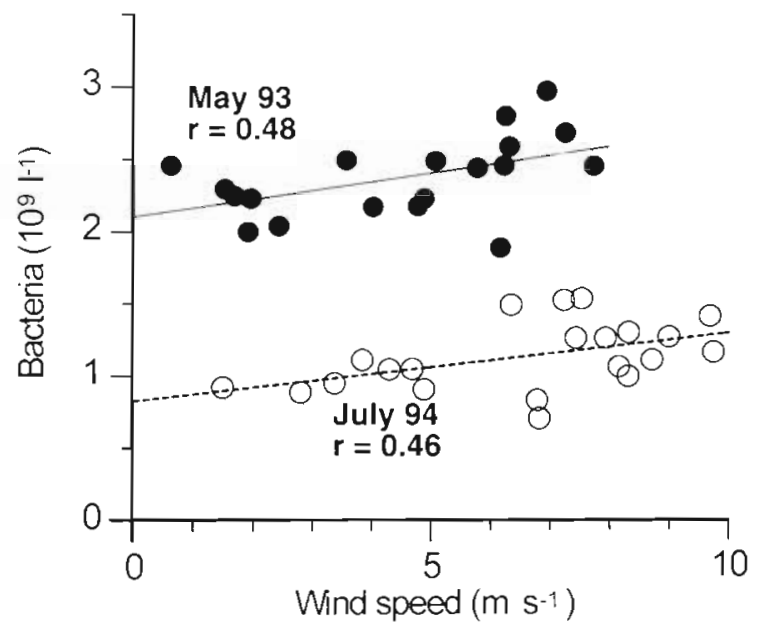

Fig. 6. Reidtionship between bacterial abundance and wind speed averaged over the $24 \mathrm{~h}$ before sampling during May 1993 and July 1994 study periods

Rangiroa atoll near Tikehau atoll (Lenhardt 1991). We thus divided the datasets from the 2 last field trips according to this value $\left(5 \mathrm{~m} \mathrm{~s}^{-1}\right)$. On average, bacterial abundance was between 10 and $20 \%$ greater during the days where wind speed exceeded $5 \mathrm{~m} \mathrm{~s}^{-1}(\mathrm{p}<0.05)$. The influence of wind speed on bacterioplankton production and other parameters was not significant.

Seasonal variations. We are aware that a seasonal trend determined using average values at different seasons spread over 3 years could be biased by interannual variations. However, the amplitude of seasonal variation may be evaluated using the results of the 6 field trips distributed through the year from January 1991 to August 1994 and covering the rainy season (November to March) and the dry season (April to October). Table 3 shows that, except for the proportion of attached cells, the maximum variation was a factor of 3 for TTI/cell. This was mostly due to variation in abundance. Indeed, bacterial abundance $(C V=34 \%)$ appears to fluctuate more than bacterial production as reflected by $\operatorname{TdR}(\mathrm{CV}=10 \%)$ and Leu incorporation $[\mathrm{CV}=11 \%)$. These slight fluctuations did not show any evident seasonal trend. Moreover, the differences between the 2 field trips in November 1991 and 1992 are almost equal to the differences between the other field trips (see Fig. 7).

\section{DISCUSSION}

\section{Spatial variations}

In Tikehau lagoon, vertical profiles of bacterioplanktonic abundance and activity in different seasons show that homo- 
Table 3. Average (Avg.), coefficient of variation (CV\%) and maximum amplitude ( $\mathrm{Max} / \mathrm{min}$ ) of bacterioplankton variables in surface water $(0.5 \mathrm{~m}$ deep) of Tikehau lagoon recorded daily during each study period. Symbols and units as in Table 1

\begin{tabular}{|c|c|c|c|c|c|c|c|c|}
\hline Study period & & Cells & FDDC & $\%$ ATT & TTI & Leu & TTI/cell & Leu/cell \\
\hline $\begin{array}{l}\operatorname{Jan} 1991 \\
(6 \mathrm{~d})\end{array}$ & $\begin{array}{c}\text { Avg } \\
\text { CV \% } \\
\text { Max/min }\end{array}$ & $\begin{array}{l}1.39 \\
17 \\
1.5\end{array}$ & & & & & & \\
\hline $\begin{array}{l}\text { Nov } 1991 \\
{[6 \text { d] }}\end{array}$ & $\begin{array}{c}\text { Avg. } \\
\text { CV\% } \\
\text { Max/min }\end{array}$ & $\begin{array}{l}0.97 \\
16 \\
1.7\end{array}$ & & & $\begin{array}{c}13.9 \\
10 \\
1.4\end{array}$ & & $\begin{array}{l}14.8 \\
24 \\
2.0\end{array}$ & \\
\hline $\begin{array}{l}\text { Mar } 1992 \\
\text { (7 d) }\end{array}$ & $\begin{array}{c}\text { Avg. } \\
\text { CV \% } \\
\text { Max/min }\end{array}$ & $\begin{array}{l}1.37 \\
14 \\
1.5\end{array}$ & & & $\begin{array}{l}10.9 \\
19 \\
1.8\end{array}$ & & $\begin{array}{l}8.1 \\
23 \\
1.8\end{array}$ & \\
\hline $\begin{array}{l}\text { Nov } 1992 \\
(14 \text { d) }\end{array}$ & $\begin{array}{c}\text { Avg. } \\
\text { CV \% } \\
\text { Max/min }\end{array}$ & $\begin{array}{l}1.90 \\
25 \\
2.1\end{array}$ & $\begin{array}{l}7.5 \\
16 \\
2.1\end{array}$ & 2.4 & $\begin{array}{l}12.9 \\
26 \\
2.2\end{array}$ & $\begin{array}{l}135 \\
24 \\
2.0\end{array}$ & $\begin{array}{l}7.1 \\
33 \\
2.9\end{array}$ & $\begin{array}{l}72 \\
24 \\
2.0\end{array}$ \\
\hline $\begin{array}{l}\text { May } 1993 \\
(19 \text { d) }\end{array}$ & $\begin{array}{c}\text { Avg. } \\
\text { CV\% } \\
\text { Max/min }\end{array}$ & $\begin{array}{l}2.37 \\
11 \\
1.6\end{array}$ & $\begin{array}{l}8.1 \\
22 \\
2.3\end{array}$ & 2.1 & $\begin{array}{l}11.9 \\
18 \\
1.9\end{array}$ & $\begin{array}{l}168 \\
18 \\
1.9\end{array}$ & $\begin{array}{l}5.1 \\
20 \\
2.3\end{array}$ & $\begin{array}{l}71 \\
17 \\
2.2\end{array}$ \\
\hline $\begin{array}{l}\text { Aug } 1994 \\
(21 \mathrm{~d})\end{array}$ & $\begin{array}{c}\text { Avg. } \\
\text { CV\% } \\
\text { Max/min }\end{array}$ & $\begin{array}{l}1.12 \\
20 \\
2.2\end{array}$ & $\begin{array}{l}12.8 \\
12 \\
1.5\end{array}$ & 10.3 & $\begin{array}{c}11.4 \\
18 \\
1.8\end{array}$ & $\begin{array}{l}160 \\
26 \\
2.9\end{array}$ & $\begin{array}{l}10.4 \\
21 \\
2.3\end{array}$ & $\begin{array}{l}146 \\
28 \\
3.6\end{array}$ \\
\hline Mean for avg. & & 1.52 & 9.5 & 4.9 & 12.2 & 155 & 9.1 & 96 \\
\hline $\mathrm{CV}^{\mathrm{a}}$ & & 34 & 31 & 95 & 10 & 11 & 41 & 44 \\
\hline Max/mind & & 2.4 & 1.7 & 5.0 & 1.3 & 1.2 & 2.9 & 2.0 \\
\hline
\end{tabular}

geneity is the rule at the scales considered here. Vertical homogeneity of nutrients (Charpy-Roubaud et al. 1990) has been reported previously in this lagoon. Chl a, POC, PON, and ATP are also distributed homogeneously except in the near-bottom layer $1 \mathrm{~m}$ above sediments) where chl $a$, POC, and PON increase on average by $30 \%$ (Charpy \& Charpy-Roubaud 1991). The bottom layer was not investigated systematically during this study but the samples that were taken revealed no discernible differences compared to other levels in another atoll lagoon (Takapoto; authors' unpubl. data). The vertical homogeneity is probably caused by wind mixing due to constant eastern trade winds (4.9 $\mathrm{m} \mathrm{s}^{-1}$ annual average; Lenhardt 1991).

The study of horizontal variations shows some differences. Bacterial growth rate may vary 20 -fold from $1.5 \mathrm{~d}^{-1}$ near the wharf under human influence to $0.08 \mathrm{~d}^{-1}$ near the reef-flat spillway where oceanic waters are entering into the lagoon (see Figs. $3 \& 5$ ). However, these departures from average conditions in the lagoon are very limited in space $(<300 \mathrm{~m}) \mathrm{com}-$ pared to the whole lagoon (smallest diameter $17 \mathrm{~km}$ ).

Oceanic waters flowing over the reef-flat through the reference spillway are significantly altered. Cell

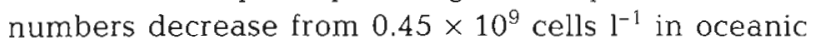
waters to $0.3 \times 10^{9}$ cells $l^{-1}$ in the reef-flat spillway. This might be interpreted as the result of grazing by filter feeders abundant on the outer reef crest and inside the reef-flat spillway. A similar decrease in abundance was observed by Linley \& Koop (1986) in water flowing over One Tree Island Reef. They observed a decrease of bacterial numbers from 6.8 (upstream) to $2.5 \times$ $10^{9}$ cells $\mathrm{I}^{-1}$ (downstream) along a $2500 \mathrm{~m}$ transect over

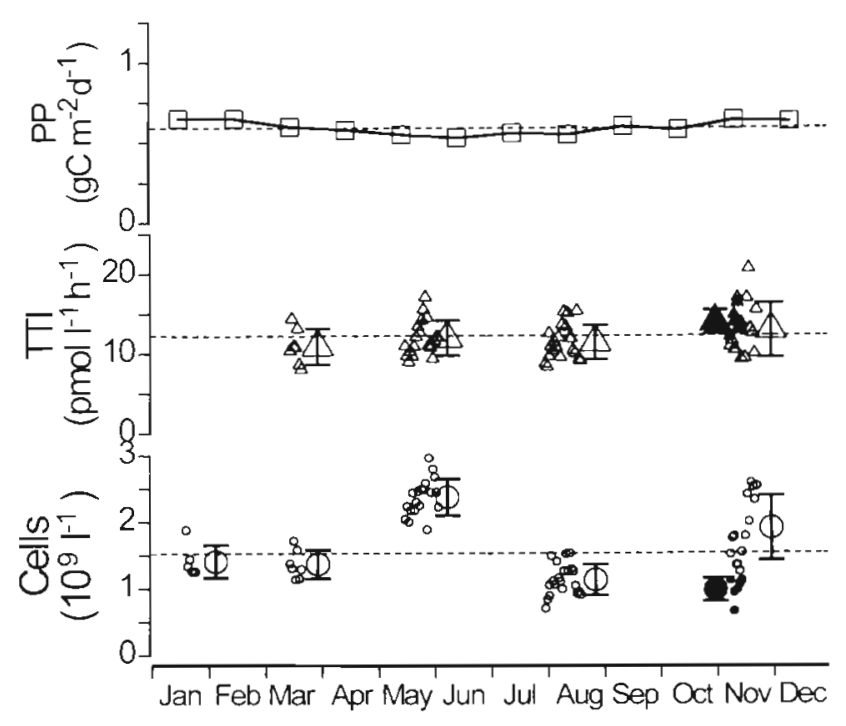

Fig. 7. Plots of bacterial abundance (Cells) and TdR incorporation (TTI) obtained by daily sampling at the lagoon reference station during the 6 different study periods. Small symbols represent single values. Large symbols and error bars represent average and standard deviation per study period. For November: $(\bullet, 4) 1991$ data, and $(0, \Delta) 1992$ data. Primary production (PP) monthly averages ( $\square$ ) are calculated from the model proposed by Charpy \& Charpy-Roubaud (1990). Dotted lines represent average for all study periods 
One Tree Island Reef (Great Barrier Reef) and interpreted this difference as resulting from benthic grazing of inflowing bacteria. A comparable study in Davies Reef and Myrmidon Reef (Great Barrier Reef) also showed a net decrease of planktonic microbial communities during water flow over the reef (Ayukai 1995). The proportion of attached bacteria increased during inflow through the spillway. This increase may be due to resuspension of benthic cells and/or release by benthos of particles rich in bacteria (like coral mucus or pseudofeces). Rapid colonization of particles by planktonic bacteria is unlikely considering that the average bacterial turnover time was $5 \mathrm{~d}$ in the reef-flat spillway (Table 1). With an average flow velocity of $513 \mathrm{~m} \mathrm{~h}^{-1}$ during the tidal period studied, the average waier residence time in the spillway (800 $\mathrm{m}$ long) was $1.6 \mathrm{~h}$. While this residence time is likely underestimated, as oceanic water may stay longer over the external reef-flat, the real value is probably closer to several hours than to several days, Cell-specific TdR and Leu incorporation rates increase during the transit, probably in response to enriched conditions in the reef-flat spillway. Indeed, the increase of the Leu/TdR ratio suggests unbalanced growth in the spillway, probably due to a shift up in the growth conditions (Chin-Leo \& Kirchman 1990) as protein synthesis is expected to react more rapidly than DNA synthesis. The limited depth $(0.5$ to $1 \mathrm{~m})$ inside the spillway could lead to a close coupling between phytobenthic and bacterioplanktonic production during the minimum flow. Unbalanced growth reflected by the increase of the Leu/TdR ratio is consistent with an enrichment of the water during the passage in far less time than the average bacterial generation time.

Similar to the local eutrophication near the village, the influence of reef-flat spillway waters is, however, also likely to be negligible at the lagoon scale. Therefore, the horizontal homogeneity observed in nutrients, organic matter and chlorophyll seems to hold for bacterioplanktonic parameters in Tikehau lagoon.

There are very few other data on horizontal variations of bacterial parameters in atoll lagoons. Strong horizontal variations were reported in Sorokin's (1978) pioneering work on the Majuro atoll lagoon with bacterial abundances ranging from 0.06 to $0.55 \times 10^{9}$ cells $\mathrm{l}^{-1}$ We calculated a coefficient of variation of $60 \%$ around the mean value using his data ( $n=7$, excluding reef and village stations). However, this variability may have been due to methodological artifacts. Sorokin (1978) enumerated bacteria on cellulose ester membranes. The smallest cells may have been hidden in the membrane matrix as suggested by the very low bacterial numbers he reported. Moreover, a more recent study using standard methods showed greater homogeneity ( $\mathrm{CV}=18 \%, \mathrm{n}=6)$ and higher microbial abun-

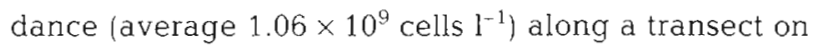
the same lagoon (Yoshinaga et al. 1991). At present, the limited number of published reports prevents generalization of bacterial homogeneity in oceanic atoll lagoons but other data in the Tuamotu lagoons support this hypothesis (Torréton unpubl. data).

\section{Temporal variations}

Diurnal fluctuations are limited as CV values are less than $20 \%$ with no consistent trend with time of day. The weak diurnal variations observed in Tikehau lagoon contrast with those often reported over coral reef environments (Moriarty et al. 1985, Linley \& Koop 1986). Strong diurnal variations are often interpreted as resulting from a close coupling between important sources of organic matter fluctuating over the same periods (e.g. algal exudation, yrazing, excretion of coral mucus) or from water movements due to tidal fluctuations. Moriarty et al. (1985) reported coefficients of variation less than $20 \%$ for bacterial abundance in open water, fore reef and reef-flat at Lizard Island while production values varied much more over the reef-flat and reef front $(\mathrm{CV}=106$ and 101\%, respectively) than in open water (CV $=26 \%$ ). They interpreted the increase in the afternoon as a consequence of a close coupling between DOC released by benthic primary producers and subsequent bacterial utilization. An inconsistent diel pattern and a weak diel amplitude in Tikehau lagoon suggests a weak coupling between primary and bacterioplankton production. Moreover, these results show that a single sampling of the lagoon may thus be considered as representative of the daily value within less than $20 \%$.

Day-to-day variations were moderate with a CV around $20 \%$ over 1 to $3 \mathrm{wk}$ of daily sampling. When it was possible to record wind speed, a significant correlation was observed with bacterial abundance. The most likely explanation for an increase of bacterial abundance without a concomitant increase in bacterial activity is by sediment resuspension. Lagoon sediments generally present bacterial abundances 1000 times greater than in the equivalent volume of the water column (Ducklow 1990), thus bacteria in the top $1 \mathrm{~cm}$ of lagoon sediments would contain a bacterial abundance equivalent to around $40 \%$ of the total for a $25 \mathrm{~m}$ water column (average depth in Tikehau lagoon). While the redistribution of bacteria from the first $1 \mathrm{~cm}$ of sediment on the whole water column is very unlikely, this rough calculation shows that wind-induced resuspension of sediments may increase bacterial abundance in the water column. This is in agreement with Wainright's (1990) flume experiments showing an input of benthic microbial biomass in the water col- 
umn. Resuspension of benthic bacteria was also apparent from the results of storm simulation in benthic/ pelagic mesocosms (Chróst \& Riemann 1994) and was observed after a storm event in the benthic turbidity layer of Kiel Bight, Germany (Ritzgrau \& Graf 1992). In coral reef areas, increasing bacterial biomass with increasing wind speed was reported at Lizard Island (Moriarty 1979). Sediments from Tikehau lagoon are generally anoxic within the top $1 \mathrm{~cm}$ (C. Hily unpubl. data). Benthic anaerobic bacteria are likely dominated by sulfate reducing bacteria in such a marine environment. These bacteria are known to be unable to incorporate exogenous TdR (Gilmour et al. 1990, Wellsbury et al. 1993), their resuspension is thus likely to present a negligible short-term influence at least on TdR incorporation rates. Sediment resuspension could increase the amount of organic matter available to bacteria in the water column, thus increasing bacterial activity over periods longer than 24 h (Chróst \& Riemann 1994 and references therein). However, our short time series (19 and 21 consecutive days) prevent us from analysing long-term effects of wind speed on bacterial parameters. Our data show, however, that wind forcing can lead to significant increases of bacterial abundances in the water column within $24 \mathrm{~h}$. This may represent a significant source of day-to-day variability of bacterioplankton abundance and might be especially important in shallower lagoons.

We were unable to detect any seasonal trend by comparing data from different trips made during the 2 characteristic seasons as the differences were very limited on average. Moreover, differences between the 2 November trips were in the same range as differences between seasons. The description of a complete seasonal cycle would have required sampling on at least a monthly basis over more than 1 yr. However, if a seasonal cycle exists, it should be rather limited both in terms of importance and time and in any case fluctuations of bacterial production like in the Great Barrier Reef would have been detected. Indeed, the weak differences observed in Tikehau lagoon at different seasons contrast with previous work performed on the Great Barrier Reef. Moriarty et al. (1985) report a difference up to 25 -fold between summer and winter bacterial production values at Lizard Island. These strong differences are likely due to the small distance from Lizard Island Reef to the continent as both are at the same latitude. It is interesting to note that, in Tikehau, bacterioplankton abundance shows greater variation than bacterioplankton production determined using TTI. We have shown that bacterial abundance was correlated with wind forcing but not bacterial production. Wind speed could be responsible for a part of the observed inter-cruise differences in bacterial abundance. Unfortunately, the absence of wind records dur- ing these field trips prevents us from resolving this question.

To our knowledge there are no comparable data on seasonal fluctuations of heterotrophic bacterioplankton biomass and productivity in fully oceanic atoll lagoons. Our study shows a remarkable stability of bacterioplanktonic processes over a range of temporal and spatial scales, especially compared to other coral reef areas. This atypical stability may be due to a number of factors including stability of the atmospheric and oceanic environments, the limited exchange between lagoon and ocean, and the limited terrestrial sources for microbial growth.

Stability of oceanic and atmospheric environment. The hydrological characteristics of oceanic water bordering the Tuamotu archipelago, situated in the South Pacific Gyre, are quite constant throughout the year (Rougerie 1979). This stability is shared with other low latitudinal gyral regions (Blackburn 1991).

Tikehau lagoon has a weak seasonal cycle with water temperature ranging from $26^{\circ} \mathrm{C}$ in July to $30^{\circ} \mathrm{C}$ in March (Lenhardt 1991). Primary production has only a small seasonal amplitude (Fig. 7). The annual average of the sum of benthic and pelagic primary production is $0.59 \mathrm{~g} \mathrm{C} \mathrm{m}^{-2} \mathrm{~d}^{-1}$ (Charpy \& Charpy-Roubaud 1990). Mean monthly values range from 0.53 to $0.65 \mathrm{~g}$ $\mathrm{C} \mathrm{m}^{-2} \mathrm{~d}^{-1}$ in June and February, respectively, showing only a 1.2 -fold variation through the year. This cycle is mostly due to the seasonal cycle of irradiance, which varies 1.5 -fold between the same periods. It is worth noting that the seasonal amplitude of irradiance is much less than day-to-day variations (Charpy \& Charpy-Roubaud 1990).

Wind forcing was shown to have a positive influence on at least bacterial biomass in the water column. However, the complete resuspension of the top $1 \mathrm{~cm}$ of sediments would increase bacterial concentration by only $40 \%$ if bacteria are 1000 times more abundant per unit volume in sediments than in the water column (see above). Except in shallower lagoons or during storms, the potential importance of sediment resuspension is limited.

Limited importance of exchanges between the lagoon and the ocean. Water residence time in Tikehau lagoon is long (170 d; Lenhardt 1991) compared to bacterial generation time in the lagoon (4.6 d on average using TTI/cell values in Table 3 ). The shift-up conditions observed during the passage of oceanic water into the lagoon through the reef-flat spillways are therefore practically insignificant at the scale of the lagoon. This leads to limited importance of exchanges between the lagoon and the ocean at the 'bacterial scale'.

Limited sources of organic matter. The area near the wharf shows a significant elevation in bacterial 
production compared to the main part of the lagoon However, this bacterial production is only 6 times greater than at the reference station (Fig 3) and is limited to less than $100 \mathrm{~m}$ from the wharf. Potential enrichment from this source appears to be minor at the scale of the lagoon. Bacteria had higher growth rates in the reef-flat spillways than in oceanic waters, suggesting that incoming oceanic waters are enriched during the passage over the reef-flat. This enrichment is quite limited, however, as the effect is limited to less than $200 \mathrm{~m}$ inside the lagoon during average inflow conditions. This limited potential enrichment through the reef-flat spillway is also obvious from the comparison between water and bacterial turnover times ( $170 \mathrm{~d}$ and $4.6 \mathrm{~d}$, respectively).

In contrast to continental or island lagoons, oceanic atoll lagoons are generally bordered by coral islands with a low surface area compared to that of the lagoon. In Tikehau, these islands represent only $25 \mathrm{~km}^{2}$. around $6 \%$ of the lagoon surface area, and are composed of very poor coral sand substrate. Terrestrial inputs should represent a minor potential source of organic matter or nutrients for the lagoon.

Finally, at the temporal scales investigated, bacterioplanktonic biomass and activity appear to be very stable in Tikehau lagoon compared to other coral reef areas. This relative temporal stability shows that determining bacterial abundance and activity during a single campaign in Tuamotu atoll lagoons should give a reasonable estimate of these variables all over the year.

However, this relative stability at the scales investigated is not the only difference. With $1.52 \times 10^{9}$ cells $^{-1}$ (Table 3), mostly free living cells in Tikehau lagoon, average bacterioplankton biomass represents about $23 \mu \mathrm{g} \mathrm{C} \mathrm{l}{ }^{-1}$ [using Simon \& Azam's (1989) carbon conversion factor] and exceeds autotrophic planktonic biomass (12.5 $\mu \mathrm{g} \mathrm{Cl}^{-1}$, Blanchot et al. 1989). This suggests that bacteria represent a considerable proportion of carbon standing stock in the water column in the smallest size classes. This contribution may be even more important for nitrogen as the bacterial $\mathrm{C} / \mathrm{N}$ ratio is around 5 (review by Hollibaugh et al. 1991). The sequestration of carbon and nutrients in the smallest size classes (spherical equivalent diameter $0.4 \mu \mathrm{m}$ ) which are less available to grazers may be especially important in these ecosystems.

Generation times $(1 / \mu)$ are long in the lagoon (average for all field trips $4.6 \mathrm{~d}$ using TdR data in Table 3 ) despite the average temperature $\left(28\right.$ to $\left.30^{\circ} \mathrm{C}\right)$, and are in the range reported by Yoshinaga et al. (1991) for Majuro atoll lagoon (1.2 to 5.2 d). These generation times are longer than those usually reported $(<1 \mathrm{~d})$ in other coral reef areas. This suggests that heterotrophic bacterioplankton is limited by bottom-up processes in Tikehau lagoon. The consequences of these high bio- masses and low growth rates will be treated in further publications

Acknowledgements. Thus work was supported by ORSTOM grants on the CYEL program and by PNRCO (Programme National 'Récifs Coralliens', INSU-ORSTOM). We are grateful to J. T Hollibaugh and 2 anonymous reviewers for helpful comments on the manuscript.

\section{LITERATURE CITED}

Ayukai T (1995) Retention of phytoplankton and planktonic microbes on coral reefs within the Great Barrier Reef, Australia. Coral Reefs 14:141-147

Bjornsen PK, Kuparinen J (1991) Determination of bacterioplankton biomass, net production and growth efficiency in the Southern Ocean. Mar Ecol Prog Ser 71:185-194

Blackburn A (1991) Low latitude gyral regions. In: Longhurst AR (ed) Analysis of marine ecosystems. Academic Press, London, p 3-29

Blanchot J, Charpy L, Le Borgne R (1989) Size composition of particulate organic unatles in the layoun of Tikehau atoll (Tuamotu archipelago). Mar Biol 102:329-339

Charpy L, Charpy-Roubaud CJ (1990) A model of the relationship between light and primary production in an atoll lagoon. J Mar Biol Ass UK 70:357-369

Charpy L, Charpy-Roubaud CJ (1991) Particulate organic matter fluxes in a Tuamotu atoll lagoon (French Polynesia). Mar Ecol Prog Ser 71:53-63

Charpy-Roubaud CJ, Charpy L, Cremoux JL (1990) Nutrient budget of the lagoonal waters in an open central South Pacific atoll (Tikehau, Tuamotu, French Polynesia). Mar Biol 107:67-73

Chin-Leo G, Kirchman D (1990) Unbalanced growth in natural assemblages of marine bacterioplankton. Mar Ecol Prog Ser 63:1-8

Cho BC, Azam F (1990) Biogeochemical significance of bacterial biomass in the ocean's euphotic zone. Mar Ecol Prog Ser 63:253-259

Chróst RJ, Riemann B (1994) Storm-stimulated enzymatic decomposition of organic matter in benthic/pelagic coastal mesocosms. Mar Ecol Prog Ser 108:185-192

Crossland CJ, Bames DJ (1983) Dissolved nutrients and organic particulates in water flowing over coral reefs at Lizard Island. Aust J Mar Freshwater Res 34:835-844

Ducklow HW (1984) Geographical ecology of marine bacteria: physical and biological variabilıty at the mesoscale. In: Klug MJ, Reddy CA (eds) Current perspectives in microbial ecology. American Society for Microbiology, Washington, DC, p 22-31

Ducklow HW (1990) The biomass, production and fate of bacteria in coral reefs. In: Dubinsky $Z$ (ed) Coral reefs. Elsevier, Amsterdam, p 265-289

Dufour P, Torréton JP (1996) Bottom-up control of bacterioplankton from eutrophic to oligotrophic sites in the North Eastern tropical Atlantic ocean. Deep Sea Res I 43(8): $1305-1320$

Fuhrman JA, Azam F (1982) Thymidine incorporation as a measure of heterotrophic bacterioplankton production in marine surface waters: evaluation and field results. Mar Biol 66:109-120

Gilmour CC, Leavitt ME, Shiaris MP (1990) Evidence against incorporation of exogenous thymidine by sulfate-reducing bacteria. Limnol Oceanogr 35:1401-1409

Hollibaugh JT, Buddemeier RW, Smith SV (1991) Contributions of colloidal and high molecular weight dissolved 
material to alkalinity and nutrient concentrations in shallow marine and estuarine systems. Mar Chem 34:1-27

Hoppe HG, Schramm W, Bacolod P (1988) Spatial and temporal distribution of pelagic microorganisms and their proteolytic activity over a partly destroyed coral reef. Mar Ecol Prog Ser 44:95-102

Kinsey DW, Hopley D (1991) The significance of coral reefs as a global carbon sink. Response to Greenhouse. Paleogr Paleoclimatol Paleoecol 89:363-377

Kirchman DL, K'Nees E, Hodson R (1985) Leucine incorporation and its potential as a measure of protein synthesis by bacteria in natural aquatic systems. Appl Environ Microbiol 49:599-607

Landry MR, Haas LW, Fagerness VL (1984) Dynamics of microbial plankton communities: experiments in Kaneohe Bay, Hawaii. Mar Ecol Prog Ser 16:127-133

Leborgne R, Blanchot J, Charpy L (1989) Zooplankton of the lagoon of Tikehau (Tuamotu Archipelago) and its relationship to particulate matter. Mar Biol 102:341-353

Lenhardt X (1991) Hydrodynamique des lagons d'atoll et d'île haute en Polynésie Française. ORSTOM Etudes et thèses, ORSTOM, Paris

Linley EAS, Koop K (1986) Significance of pelagic bacteria as a trophic resource in a coral reef lagoon, One Tree Island, Great Barrier Reef. Mar Biol 92:457-464

Moriarty DJW (1979) Biomass of suspended bacteria over coral reefs. Mar Biol 53:193-200

Moriarty DJW, Pollard PC, Hunt WG (1985) Temporal and spatial variation in bacterial production in the water column over a coral reef. Mar Biol 85:285-292

Moriarty DJW, Roberts DG, Pollard PC (1990) Primary and bacterial productivity of tropical seagrass communities in the Gulf of Carpentaria, Australia. Mar Ecol Prog Ser 61: $145-157$

Newell SY, Christian RR (1981) Frequency of dividing cells as an estimator of bacterial productivity. Appl Environ Microbiol 42:23-31

Paul JH, DeFlaun MF, Jeffrey WH (1986) Elevated levels of microbial activity in the coral surface microlayer. Mar Ecol Prog Ser 33:29-40

Responsible Subject Editor: J. Dolan, Villefranche-sur-Mer, France
Porter KG, Feig YS (1980) The use of DAPI for identifying and counting aquatic microflora. Limnol Oceanogr 25:943-948

Ritzgrau W. Graf G (1992) Increase of microbial biomass in the benthic turbidity zone of Kiel Bight after resuspension by a storm event. Limnol Oceanogr 37:1081-1086

Rougerie F (1979) L'environnement de l'atoll de TakapotoTuamotu. J Soc Océanistes 33:35-45

Schiller C, Herndl GJ (1989) Evidence of enhanced microbial activity in the interstitial space of branched corals: possible implications for coral metabolism. Coral Reefs 7 : $179-184$

Simon M. Azam F (1989) Protein content and protein synthesis rates of planktonic marine bacteria. Mar Ecol Prog Ser $51: 203-213$

Smith SV (1978) Coral reef area and the contributions of reefs to the processes and resources in the world's oceans Nature 273:225-226

Snedecor GW, Cochran WG (1957) Statistical methods, 6th edn. The Iowa State University Press, Ames

Sorokin Y (1973) Trophical role of bacteria in the ecosystem of the coral reef. Nature 242:415-417

Sorokin Y (1978) Microbial production in the coral reef community. Arch Hydrobiol 83:281-323

Stoddart DR (1965) The shape of atolls. Mar Geol 3:369-383

Torréton JP, Dufour P (1996) Bacterioplankton production determined by DNA synthesis, protein synthesis and frequency of dividing cells in Tuamotu atoll lagoons and surrounding ocean. Microb Ecol 32:185-202

Yoshinaga I, Fukami K, Ishida Y (1991) Comparison of DNA and protein synthesis growth rates of bacterial assemblages between coral reef waters and pelagic waters in tropical ocean. Mar Ecol Prog Ser 76:167-174

Wainright SC (1990) Sediment-to-water fluxes of particulate material and microbes by resuspension and their contribution to the planktonic food web. Mar Ecol Prog Ser 62: 271-281

Wellsbury P, Herbert RA, Parkes RJ (1993) Incorporation of [methyl $-{ }^{3} \mathrm{H}$ |thymidine by obligate and facultative anaerobic bacteria when grown under defined culture conditions. FEMS Microb Ecol 12:87-95

Manuscript first received: February 20, 1996

Revised version accepted: September 26, 1996 